\title{
The Role of Community Radio in Empowering Women in India
}

Yalala $\mathbf{N}^{*}$

Assistant Professor (C) and Ph.D. Scholar in the Department of Communication and Journalism, Osmania University, Hyderabad -500 007, India

\begin{abstract}
Community radio is a third tier broadcasting along with public and private radio broadcasting. Community radio is managed, run, controlled and owned by a community for the benefit of the community and serves the needs, interests and aspirations of a community. CR (Community Radio) gives marginalized communities where their voice is not heard earlier, the CR gives them an opportunity to express their views where in the mainstream media these voices are not provided any space or time. Voluntary organizations, civic groups, NGO's, Women's groups/organizations, etc. are now entering into broadcasting to share, express, empower, give voice, to many communities to benefit them with the broadcast. In community radio the public are voluntarily participating and producing programmes for themselves for their own benefit. CR plays an important role in the lives of women as it creates awareness, provides information and education, improves their skills and on the whole it promotes social, cultural, political and economic development or empowerment of women. Many studies have proved that community radio is an instrument of power in changing the lives of women.
\end{abstract}

Keywords: Community radio; Community networks; Women empowerment; Community multimedia centre; Information technology

\section{Introduction of Community Radio in India}

Many non-governmental organizations and media-activist groups struggled and campaigned for setting up local radio broadcasting services to help and address the issues of their community and serve their needs, interests and aspirations. In 2007 the government announced the Community Radio Policy and all these voluntary groups joined together to constitute Community Radio Forum (CRF) of the country to support and promote the setting up of community radio stations in India. The Bangalore-based communication campaign group, 'VOICES' convened a gathering of radio broadcasters, policy planners, media professionals and not-for-profit associations in September 1996 to study how community radio could be relevant to India, and to deliberate on policies appropriate for such an action. A Declaration calling for the establishment of community broadcasting was signed. A suggestion that AIR's local stations should allocate regular airtime for community broadcasting was put forward. Requests were also made for grant of licences to NGOs and other non-profit making groups for running community radio stations. Subsequently, UNESCO made available a portable production and transmission "briefcase radio station" kit to VOICES to do experimental broadcasts of programmes for a hands-on learning experience towards the objective of setting up an independently-run community radio station [1]. By early 2003, the government of India released the first set of community radio guidelines, but restricted eligibility to educational institutions only. Marginalized and voiceless communities continued to remain outside the ambit of the then released community radio policy guidelines. Deccan Development Society (DDS), an NGO organized a workshop in Hyderabad sponsored by United Nations Educational, Scientific and Cultural Oroganisation (UNESCO) in 2000 urged the government to allocate space for community radio. Representations were made by voluntary organsations, academicians and individuals to the Ministry of Information and Broadcasting (MIB) which led the MIB to organize a workshop supported by UNDP and UNESCO in 2004 to work out a framework for community radio in India. In October 2005 the draft community radio policy was referred to a group of ministers, and finally it was approved by the Union Cabinet on November 16, 2006 which permits NGOs, educational institutions and agricultural institutions to own and operate community radio stations. In 2007, Ministry of
Information and Broadcasting Government of India announced that in the next few years, 4000 community radio stations will have sprung up under the new enabling community radio policy.

\section{The definition of community radio}

-- "A community radio station is one that is operated in the community, for the community, about the community and by the community."

The term community media, is very broad. It refers to a diverse range of mediated forms of communication: electronic media such as radio and television, print media such as newspapers and magazines, and electronic network initiatives which embrace characteristics of both traditional print and electronic media. Three of these forms are singled out for consideration: community television, community radio and community networks. When it comes to Community radio it provides a mechanism for enabling individuals, groups, and communities to tell their own stories, to share experiences and, in a media-rich world, to become creators and contributors of media.

A community radio station is characterized by its ownership and programming and the community it is authorized to serve. It is owned and controlled by a non-profit organization whose structure provides for membership, management, operation and programming primarily by members of the community at large. Its programming should be based on community access and participation and should reflect the special interests and needs of the listenership it is licensed to serve [2].

\section{Empowerment of women}

"Convinced that the full and complete development of a

*Corresponding author: Yalala N, Assistant Professor (C) and Ph.D. Scholar in the Department of Communication and Journalism, Osmania University, Hyderabad -500 007, Tel: 9912616606; E-mail: nirmala.yalala@gmail.com

Received January 13, 2015; Accepted February 18, 2015; Published February 28,2015

Citation: Yalala N (2015) The Role of Community Radio in Empowering Women in India. J Mass Communicat Journalism 5: 245. doi:10.4172/2165-7912.1000245

Copyright: @ 2015 Yalala N. This is an open-access article distributed under the terms of the Creative Commons Attribution License, which permits unrestricted use, distribution, and reproduction in any medium, provided the original author and source are credited. 
country, the welfare of the world and the cause of peace require the maximum participation of women on equal terms with men in all fields."-Preamble to Convention on the Elimination of all forms of Discrimination Against Women, 1979.

In India women comprise half of its total population. With the advent of 21st Century and its development in various scientific and technological era the status of woman are also changing at a fast pace but we cannot ignore the very existence of a world where woman are discriminated, marginalized and oppressed because of various gender divide issues. Women are vital human resources in improving the quality of life. The country's overall development depends greatly on the inclusion of women in its development process. They have been the transmitters of culture in all societies. The status of women in a society is a true index of its cultural, social, religious and spiritual level. Empowerment is essentially a transition from a position of enforced powerlessness to one of power. It promotes women's inherent strengths and positive self-image. Gaining power means acquiring ability and opportunity to participate and contribute in the social development process creatively and meaningfully. The process of empowerment enables them to develop in them self-dignity. It enables them to raise voice and fight against injustice, exploitation, abuse and violence done to them. Enjoying a powerful role in the society makes a woman empowered.

Empowerment literally means making someone powerful, facilitating the weak to attain strength, to increase one's self-esteem, to help someone to be assertive/ self-confident, to enable someone to confront injustice and oppression and to support someone to fight for her rights. 'Empowering women actually means strengthening them to confront family, community, caste, religion and traditional forces patriarchal forces and biases working within society. This confrontation ensures their full participation in every aspect of social and national development. Empowerment is a process where women, individually and collectively, become aware of how power relations operate in their lives. With this awareness they gain self-confidence and strength to challenge gender inequalities at the household, community, national 1 , regional, and international levels [3]. The term empowerment refers to a range of activities from individual self-assertion to collective resistance, protest and mobilization that challenge basic power relations. For individuals and groups where class, caste, ethnicity and gender determine their access to resources and power, their empowerment begins when they not only recognize the systemic forces that oppress them, but act to change the prevailing power relationships. Empowerment, therefore, is a process aimed at changing the nature and direction of systemic forces, which marginalized women and other disadvantaged section in a given context.

'Woman empowerment is a process that enables a powerless woman to develop autonomy, self-control and confidence and with a group of women and men, a sense of collective influence over oppressive social conditions [3]. Empowerment is a process by which the powerless gains greater control over the circumstances of their lives. It is now central in political and social, educational, cultural, sexual, personal and managerial discourses. Empowerment is related with redistribution of power. Empowerment has both personal and social aspects. At personal level it is significant change in the self-image and mental set and at the community level it is collective struggle for positive social change [3].

\section{Role of community radio in empowering women}

It is not easy to achieve women's empowerment. The resistance arises form family, society and conditioning of dis-empowered women's mentality. However, strategy for women's empowerment needs special attention. There are various methods and means for women empowerment. Some of popular methods of women empowerment include education, entrepreneurial training programmes, formation of Self Help Groups, Social Action (feminist movements), legislation, mass communication and propaganda, etc. Mass media are the chief agents of creation, preservation and eradication of different kinds of images and stereotypes of women in the contemporary world. Visual media like TV is more popular than the newspaper and magazines. The information people receive through newspapers, radio and television shapes their opinions about the world. Women are depicted in their traditional role in most of the media and their images are simply decorative in the advertising media. Media image of women in reactionary and unrealistic. Media depicts a distorted version of Indian housewife. It is the mass media which should being the process of women empowerment in the modern world. The more decision-making positions women hold in the media, the more they can influence output. They will be able to break the old stereotypes about women.

Empowering women is a major task. Government, voluntary organization, social activists and others are trying in their ways for the development of women. From the beginning of the Radio introduced in India, the primary aim of AIR (All India Radio) was to inform, educate, and entertain the public. AIR major objectives it was mentioned that radio has to serve the needs of women and it has to promote the welfare and development of women. During the 2006 when community radio policy guidelines were issued for establishing community radio stations in the country its primary aim was development of community with the help of community radio. So community radio is being thought as tool which can promote development of the country, indirectly it will promote the welfare of women.

Namma Dhwani (our voices), is the India's first cable community radio station started broadcasting in Karnataka in 2003. It was launched as a partnership effort of the Budhikote community, and NGOs MYRADA and VOICES. UNESCO has funded equipment and capacity building support. VOICES is devoted to development communication and capacity building support. All activities related to production are done in Budhikote. The listeners of community radio are illiterate women, who otherwise have little access to information. Namma Dhwani is a fully functional Community Multimedia Centre, with radio, video, and satellite facilities. It is also completely self-sufficient through locally generated revenue. Namma Dhwani enhanced the participation of women in programme making and created awareness among the women listeners about health and sanitation, education, food habits and family system and significant change was happened in the lives of women. The important aspect was that the radio developed leadership qualities/behavior among the women listeners. So it played a significant role in changing the life of the rural women [4].

Another pioneer in the field of community radio is Sangham Radio launched in Telangana (earlier in Andhra Pradesh), India, on World Rural Women's Day that is on October 15, 2008, Deccan Development Society, a non-governmental organisation (NGO) that works with 100 groups of the economically poorest Dalit women. (Sangham, referring to village level women's collectives). Sangham Radio is intended to give a voice to the excluded in general and to women in particular. This radio owned, managed, and operated exclusively by women from rural marginalised communities (the "Dalit" caste).

Manndeshi Tarang, a Community Radio Station was established 
on December 16, 2008, in Maharashtra under the sponsorship up by Mann Vikas Samajik Sanstha (MVSS), an NGO working for the empowerment of rural and margnalised women in Satara district of Mhaswad and Hubli and Dharwad in Karnataka. Mandeshi Tarang is providing relevant programming which would enrich their civic and cultural life. The community radio is operated under the guidance of the Mann Deshi Foundation, but is owned by the Mhaswad village community and surrounding coverage areas. More than 70 per cent of listeners (including women, children and men) found Mandeshi Tarang has proved to be useful to them in their life [5]. It increased their knowledge. Enabled them to showcase their talent and motivated them on various issues including education, health etc.

Another popular community radio 'Radio Namaskar', was launched in Orissa on July 11, 2010 by Young India, a civil society organization formed by some National Youth Awardees, Indira Gandhi NSS Awardees and Ex-NSS volunteers those who are committed to the cause of social transformation and development, to make the common people informative and active participant of the community development process. The test broadcasting was started on February 12, 2010 and was inaugurated formally on July 11, 2010. It was established to serve the needs, aspirations of local community. Now Radio Namaskar (90.4) is focusing on local governance, women's empowerment, food security and youth development along with the other societal need based issues. The community radio enhanced the four aspects of women (listeners and reporters) include psychological, economic, cultural, political and social. Women, both reporters and listeners, have started to reflect on their abilities and aspirations and on other women's life; their capabilities to produce communicative acts in future, through media and at an interpersonal level, seem to be stronger; they have acquired confidence in speaking in public and in challenging discriminatory traditions; their ability to make informative choices is enhanced by an improved access to a vast array of information, including women's rights; they have also acquired or improved writing skills and familiarized with Information Technology and media; to some reporters Community Radio represents a source of income and listeners increase their possibility to access employment opportunities through livelihood-related information; their consideration within family and community is improved [6]. The study concludes that four aspects of women's life are empowered through their participation in Community Radio.

Anna University, Tamilnadu the first campus radio in India was launched on February 2, 2004 called as Anna FM. The Anna University radio station is the oldest community radio station and was the first to receive a broadcast license in the country. The listeners of Anna Radio are urban low and middle class from the nearby urban clusters in a $5-10 \mathrm{~km}$ range of Anna University. A study conducted by Ester S. Kar concluded that the radio stations played an important role in social, economic, and political empowerment of women. When it comes to social empowerment it happened in terms of knowledge and skill development. In terms of political empowerment i.e. knowing the Panchayat representative, voting in assembly and general elections etc. When it comes to economic empowerment, learning job skills through radio; freedom to spend money has happened. The important aspect of community radio is it given voice to the community especially women and the marginalized. In both the cases women's empowerment among the community radio listeners is significant.

Another campus radio, Holy Cross Community Radio, Tamilnadu was launched on 26th December 2006 by Holy Cross College. The station has eight hours of transmission (including repeat transmission) a day. It reaches in and around ten kilometers of Holy Cross College. The target audience of this radio initiative were the women from Dharmanathapuram and Jeevanagar areas, which are the major slum areas in Trichy. A case study was conducted by Holy Cross College in 2008 to find out the reach and access of its community radio and its role in the community development of the local slums. The study found that $27 \%$ of the respondents participated in the Holy Cross community radio programmes and some women revealed that Holy Cross's radio programmes increased their self-confidence, generated awareness about pollution, health and hygiene and helped in their personality development.

Puduvai Vani, is established by Pondicherry University, Puducherry on December 27, 2008 with the support of University Grants Commission (UGC), New Delhi. It works under FM 107.8 $\mathrm{MHz}$ a frequency which is currently extended to a catchments area of $20 \mathrm{~km}$ radius from the University campus. The test transmission of Puduvai Vaani was started on August 23, 2008 and was inaugurated by Shri.V.Narayanasamy, the then Hon'ble Union Minister of State for Planning \& Parliamentary Affairs on December 27, 2008 in the presence of Shri. P. Chidambaram, the then Hon'ble Union Home Minister. The full time transmission started on January 1, 2009 onwards. The major objective of Puduvai Vaani is to create awareness among the people and to improve their nature of life style. Puduvai Vaani is the public broadcaster to awaken, inform, enlighten educate and entertain all section of the people including the programme on women empowerment, communal harmony, health and education. It is also bringing out the hidden talents of the students in and around the University campus. Pondicherry University conducted a study in 2012 to study the rural development of women through community radio within the area of Pillaichavady village and the data was collected from 100 women respondents. The study found out that through the Puduvai Vaani Community Radio programmes, most of the respondents nearly $87 \%$ felt improvement in education. Near to education, they got improvement in knowledge and Health also. About $64 \%$ of the respondents developed in their nutrition aspects by the programmes of Puduvai Vaani CRS. More than half of the respondents got improvement in their attitude [7].

\section{Discussion and Conclusions}

The Namma Dhwani community radio enhanced the participation of women in programme production and created awareness among the women listeners about health and sanitation, education, food habits and family system and significant change was happened in the lives of women. The important aspect was that the radio developed leadership qualities/behavior among the women listeners. Mandeshi proved to be useful to the listeners (mostly for women) in their life. It increased their knowledge and enabled them to showcase their talent and motivated them on various issues including education, health etc. Anna University played an important role in social, economic, and political empowerment of women. When it comes to social empowerment it happened in terms of knowledge and skill development. In terms of political empowerment i.e. knowing the Panchayat representative, voting in assembly and general elections etc. When it comes to economic empowerment, learning job skills through radio; freedom to spend money has happened. The important aspect of community radio is it given voice to the community especially women and the marginalized. Holy Cross Community radio proved to be women's self-confidence, generated awareness about pollution, health and hygiene and helped in their personality development. Puduvai Vani enhanced the four aspects of women (listeners and reporters- 
through their participation and listening). They include psychological, economic, cultural, political and social. Women, both reporters and listeners, have started to reflect on their abilities and aspirations and on other women's life; their capabilities to produce communicative acts in future, through media and at an interpersonal level, seem to be stronger; they have acquired confidence in speaking in public and in challenging discriminatory traditions; their ability to make informative choices is enhanced by an improved access to a vast array of information, including women's rights; they have also acquired or improved writing skills and familiarized with Information Technology and media; their consideration within family and community is improved.

Hence radio can be the source of empowerment of women. Radio can change the lives of women, it gives them voice, it gives them courage to fight for their rights, it creates awareness about various issues from the beginning the rights of women, to health, maternity, violence, nutrition. Radio also educates women about their political rights, voting, women's reservations in Panchayati Raj institutions, and Assembly, Parliament etc. It empowers them to fight back the domestic violence, male preference attitudes with men, gives them courage to speak their opinion on all issues, to express their interests. It gives them confidence to live their life. So community radio can do wonders if it used properly for the development or upliftment or empowerment of women.

\section{References}

1. Malik KK, Pavarala V (2007) Other Voices: The Struggle for Community Radio in India. Thousand Oaks, CA: SAGE Publications.

2. Fraser C, Estrada SR (2001) Community Radio Handbook. UNESCO.

3. Kumar H, Jaimon V (2005) Women's Empowerment, Issues, Challenges, and Strategies: A Source Book. Regency Publications, New Delhi.

4. Singh BK, Kumar R, Yadav KVP, Singh D, Singh HL (2010) Social Impact of Community Radio in Karnataka. Indian Res J Ext Edu 10: 10-14.

5. Ray A (2009) Impact Analysis of Mandeshi Tarang, The Community Radio of Mhaswad.

6. Bandelli D (2011) Women in Community Radio in India: Avenues of Research on Participation and Empowerment.

7. Balan KCS, Norman SJ (2012) Community Radio (CR) - Participatory Communication Tool for Rural Women Development - A Study. I Res J Social Sci 1: 19-22. 